\title{
Relationship of Learning Styles in Students of Health Sciences with Lifelong Learning
}

Mohsen Saffari

Associate Professor, Health Research Center and Dept. of Health Education, School of Health, Baqiyatallah University of Medical Sciences (BMSU), Tehran, Iran.m.saffari@bmsu.ac.ir

Hojat Rashidi-Jahan

Lecturer, Dept. of Health Education, School of Health, BMSU, Tehran, Iran . hojatr73@gmail.com

Norooz Mahmoudi

MSc. Student, Dept. of Environmental Health, School of Health, BMSU, Tehran, Iran.m.n.noroz@gmail.com

Amir Pakpour4

Associate Professor, Research Center for Social Determinants of Health, Qazvin University of Medical Sciences (QUMS), Qazvin, Iran.

pakpour_amir@yahoo.com

Hormoz Sanaeinasab

* Associate Professor, Dept. of Health Education, School of Health, Baqiyatallah University of Medical Sciences (BMSU), Tehran, Iran (Corresponding author) sanain20@yahoo.co.in

Received: 02 September 2015 Accepted: 07 September 2016

\section{ABSTRACT}

Background and objective: Learning style is one of the main components of proper educational planning. The concept of lifelong learning is also one of the valuable concepts regarding professional knowledge and skills, especially for healthcare professionals. The current study was aimed at identifying preferred learning styles among students of health faculty of the Baqiyatallah University of Medical Sciences (BMSU) and assessing the relationship between learning style and lifelong learning.

Materials and methods: In this descriptive-analytical cross-sectional study, 209 students from different health disciplines in the School of Health, BMSU were assessed. Data were collected using a demographic questionnaire, Kolb learning style inventory, and the scale of lifelong learning. Chi-square, Fisher exact test, Pearson correlation and one-way ANOVA were used with the help of SPSS 20 for data analysis.

Results: The mean age of participants was $26.69(S D=8.38)$ and the majority of them were male (94\%). Distribution of learning styles were: diverger (36\%), accommodator (34\%), assimilator (21\%), and converger (10\%). Among demographic and academic related variables only grade point average (GDP) significantly was associated with learning styles $(p<0.05)$. The mean score of lifelong learning was $45.70(S D=5.25)$. The constructs of lifelong learning had significant relationships with active experiencing and reflective observation modes of learning style. The learning styles of assimilator and diverger obtained higher scores of lifelong learning than others.

Conclusion: Regarding divergers and accommodators were more frequent than others, it is suggested that these facts be considered for a better educational planning and matching of proper teaching methods. Further research is needed to recognize the relations of learning styles with lifelong learning.

Paper Type: Research Article.

Keywords: learning, education, Students of Health Sciences, Kolb learning style inventory, scale of lifelong learning, Baqiyatallah University of Medical Sciences (BMSU).

Citation: Saffari M., Rashidi-Jahan H., Mahmoudi N., Pakpour A., Sanaeinasab H. Relationship of Learning Styles in Students of Health Sciences with Lifelong Learning. Iran J Health Educ Health Promot. Summer 2016;4(2): 89-100. 


\section{رابطه سبك يادكيرى در دانشجويان علوم بهداشتى با يادگيرى مادامالعمر}

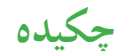

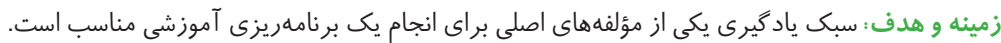

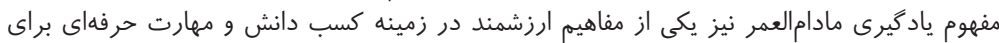

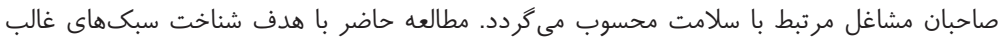

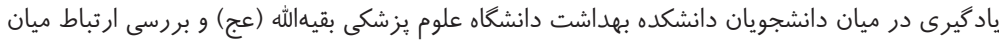

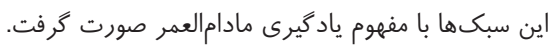

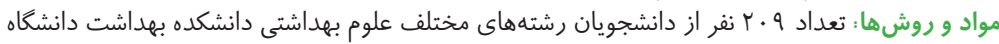

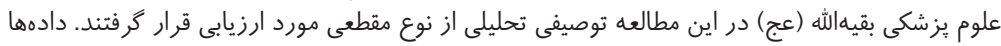

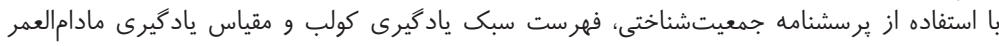

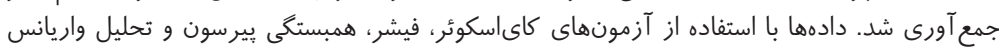

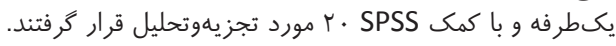

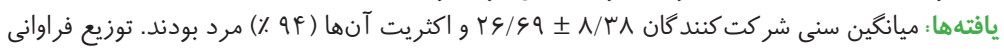

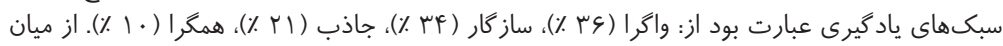

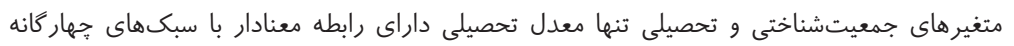

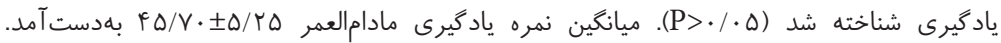

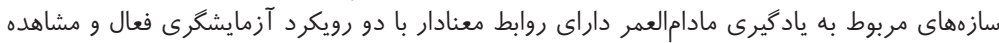

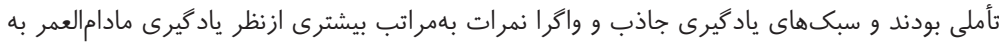

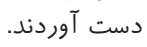

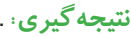

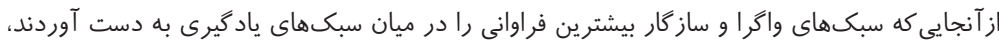

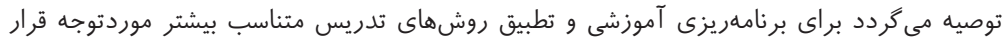

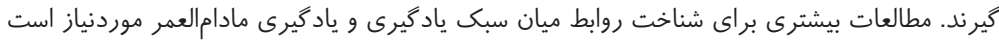

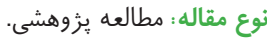

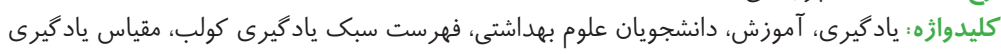
مادام العمر، دانشكاه علوم يزشكى بقيهالهه (عج).

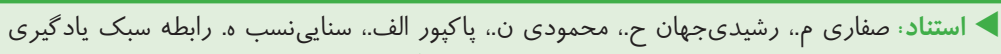

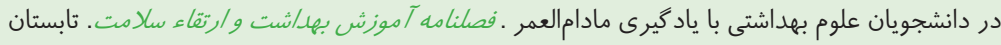

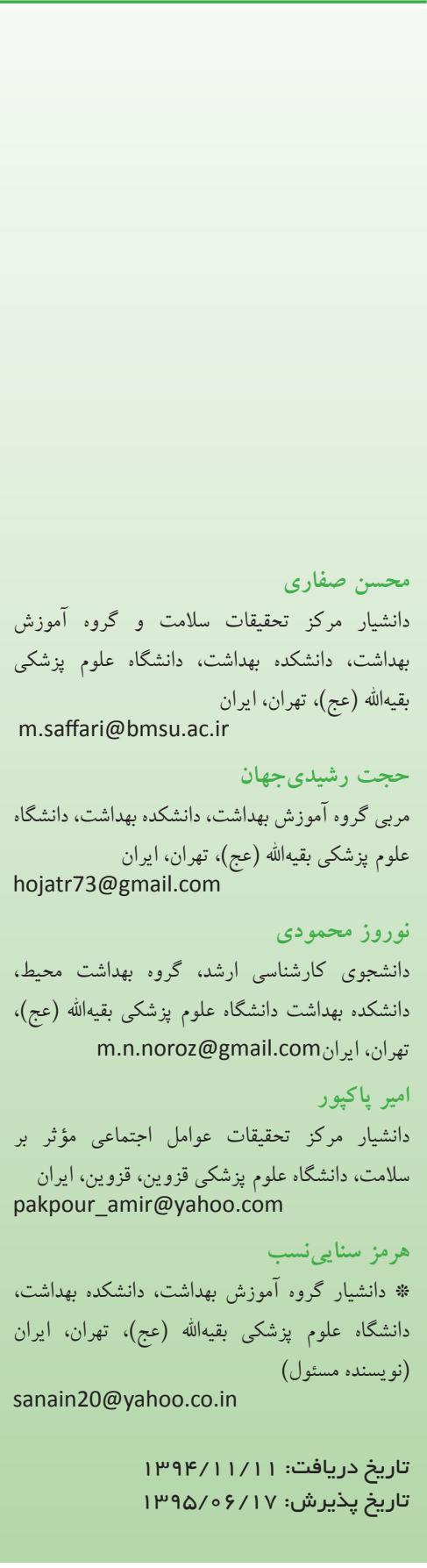


ياد گيرى اصطلاحى مهم به شمار مىرود. بهتر ين شيوه براى كمى

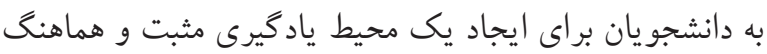
و از روشهاى تدريس متناسب با علايق دانشجويان اثربخش بـ براي استفاده كنند. كاربرد مفهوم سبك يادگيرى است. از اين كذشته، نقش اصلى معلم نيز شناسايى توان بالقوه فر اخيران براى يادگيرى و برنامهريزى كارآمد براى توسعه مهارتهاى آموزشى در

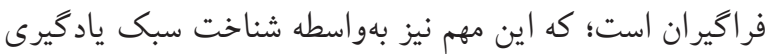
قابلدستيابى است (ه). بهطور كلى، به عقيده فلمينگ و كارنر "جهار عامل اصلى در تعيين سبك يادگيرى بايد در نظر گرفته شوند: ويزگىهاى شخصيتى، نحوه يردازش اطلاعات، تعامل اجتماعى و ترجيحات

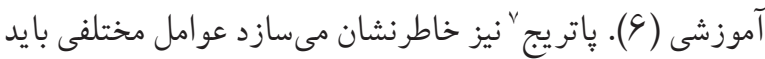

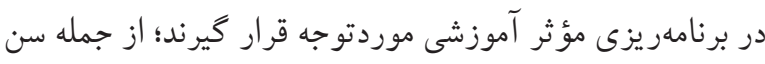
فراخيران. اين عامل يكى از عوامل كليدى براى تطبيق راهبردهاى

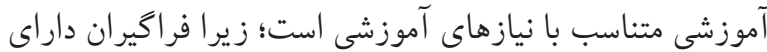

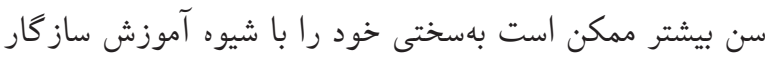

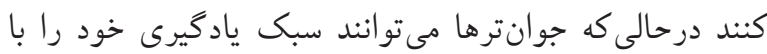
روشهاى متنوع تدريس آسانتر تطبيق دهند (V). در مطالعهاى

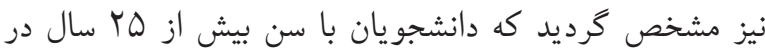
مقايسه با جوانترها محدوديت بيشترى براى تطبيق شيوه

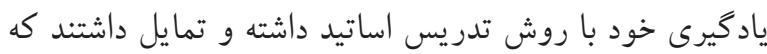
به شيوه مورد ترجيح خود به ياد گيرى بيردازند (^). عامل ديخر مى تواند جنسيت فراخيران باشد؛ به طور مثال، در مطالعهاى كه با هدف شناخت نقش جنسيت در سبك ياد گيرى دانشجويان فيزيولوزى صورت كرفت، مشخص شد كه جنس تفاوتهاى

معنادارى ازنظر توزيع سبكهاى غالب ياد گيرى دارند (9).

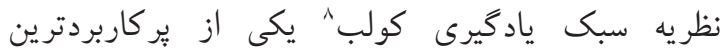
نظر يههاى مورداستفاده در زمينه شناخت سبك يادگيرى بهويزه

6. Fleming \& Garner

7. Partridge

8. Kolb learning style
بر اساس تعريف كوجينسكى،' سبك يادگيرى عبارت است از شيوه ترجيحى فرد براى يادگيرى و روشى كه فرد بهتر مى آموزد.

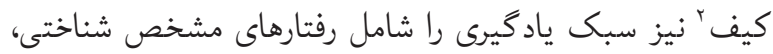
عاطفى و روانشناختى مىداند؛ كه بهعنوان شاخصهاى نسان نسبتاً يايدار نحوه ادراك، تعامل و واكنش نسبت به محيط يادگيرى

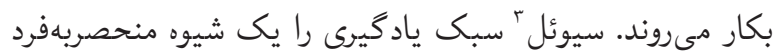

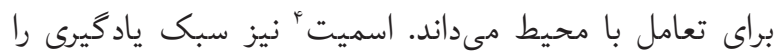

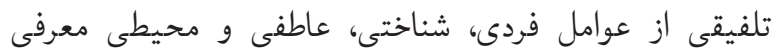
مى كند ( (1-Y). بيكز" در همين راستا دو مكتب فكرى را مطرح

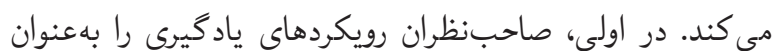
سبك مورد ترجيح براى هر نوع موقعيت يادگيرى در نظر

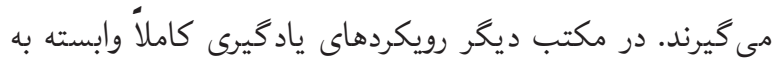

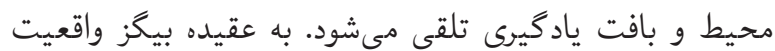

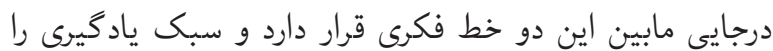

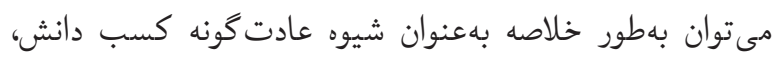

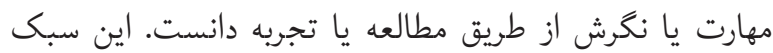
ياد گيرى مشخصهاى نسبتاً پايدار در افراد در سراسر محيطهاى يادكيرى دارد و ممكن است با تغيير بستر يادگيرى تغييرات

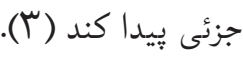
اصطلاح ((سبك ياد گيرى) مفهوم گستردهاى دارد و استفاده از

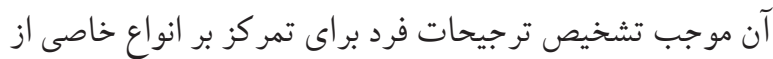
اطلاعات، روشهاى مختلف درى اطلاعات و ميزان درك و فهم

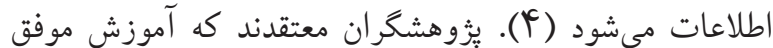

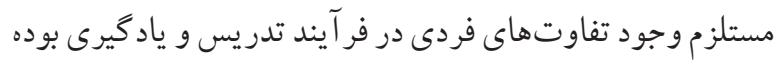
و تا جايى كه ممكن است شيوه تدريس بايد متناسب با نيازهاى فراخيران باشد. هر قدر توجه بيشترى به سبكهاى يادگيرى مختلف در فراخيران صورت گيرد، يادگيرى اثربخشترى حاصل 
صورت كرفته است. اين نوع مطالعات بيانكر اهميت درك سبك ياد كيرى براى ارزشيابى اثربخش آموزش و كيفيت كسب دانش

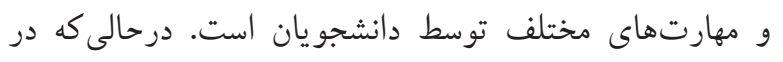

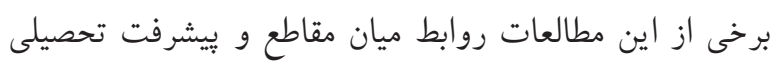

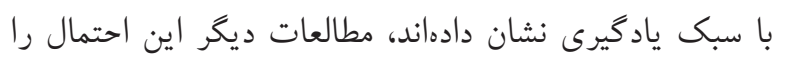

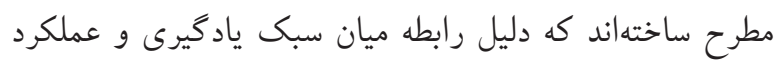
تحصيلى ممكن است تابع نوع شيوه ارزشيابى دانشجويان باشد ريد

علىرغم اهميت شناخت عوامل مرتبط با سبك يادگيرى،

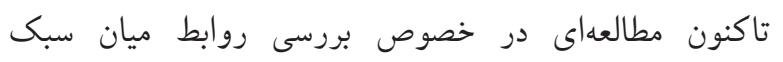

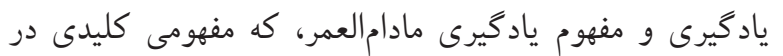
حوزه دانش يزشكى و سلامت است، صورت نغرفته است. لذا اين مطالعه حاضر قصد داشت ضمن شناخت سبكهاى يادگيرى اين دانشجويان، به ارزيابى فرضيه مربوط به روابط احتمالى ميان مفهوم سبك يادگيرى و ياد خيرى مادامالعمر بيردازد.

مو اد و روش ها اين مطالعه يك مطالعه توصيفى تحليلى از نوع مقطعى بود؛ كه

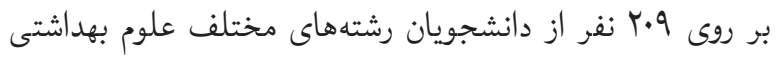
در دانشكده بهداشت دانشكاه علوم يزشكى بقيه الله (عج) در سال

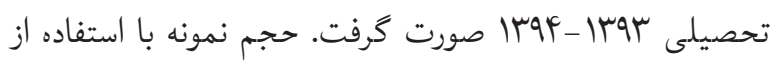
فرمول كوكران و با در نظر كرفتن سطح خطاى ه ٪ محاسبه

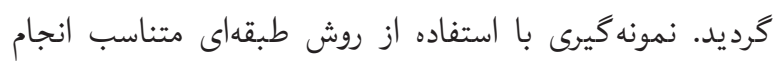

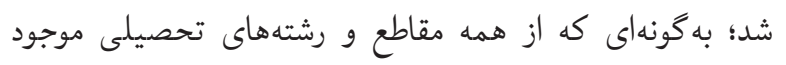
در دانشكده همه افراد بهطور متناسب شانس انتخاب در نمونه را داشته باشند. براى اين منظور، ابتدا مجوزهاى لازم براى انجام

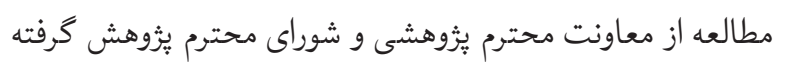

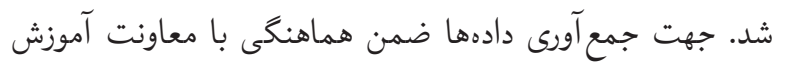

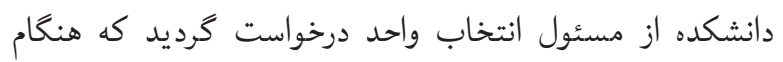
تحويل بركه انتخاب واحد مربوط به نيمسال دوم به دانشجويان،

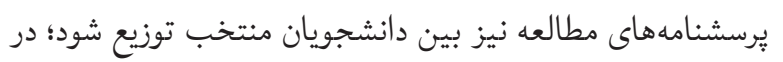

بين دانشجويان علوم يزشكى و بهداشتى است. به نظر كولب،

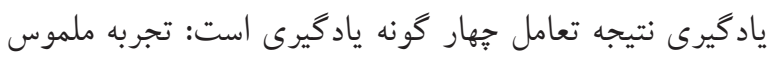
(احساس)، مفهو مسازى انتز اعى (تفكر)، مشاهده تأملى (مشاهده)

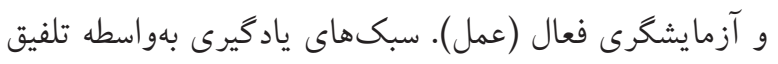

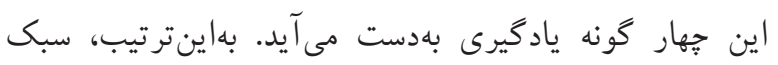

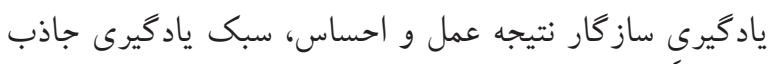

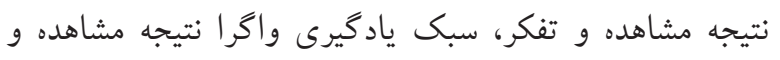
احساس و سبك يادكيرى همخر ا نتيجه تفكر و عمل است (• •(1).

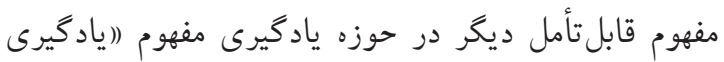

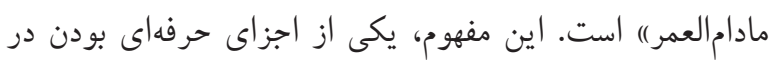

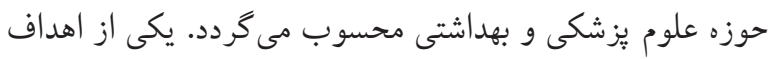

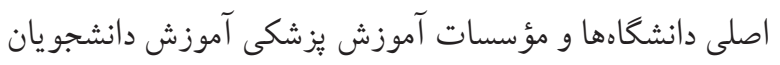

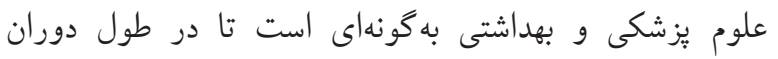

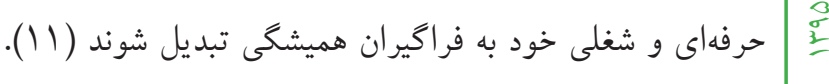

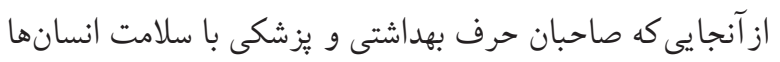

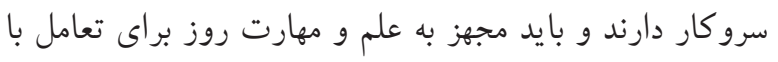

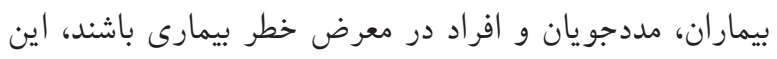

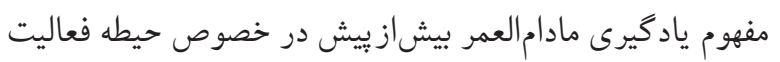
آنها مصداق داشته و بايد موردتوجه قرار كيرد. (T (I)).

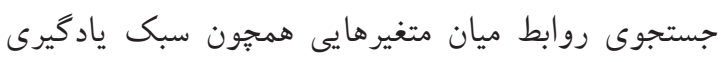

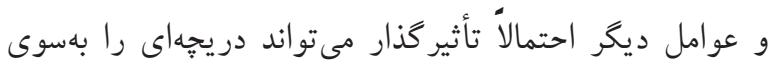
درى عميقتر از اين مفهوم و تسهيل كاربرد آن بهواسطه

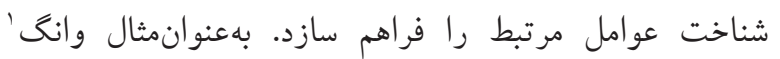

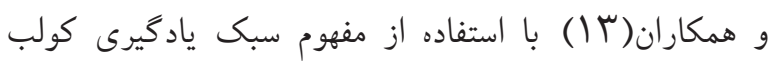
به بررسى رابطه ميان سبكهاى ترجيحى يادگيرى، عملكرد

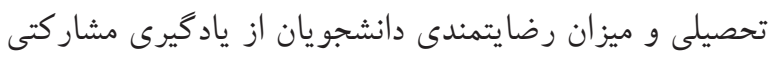

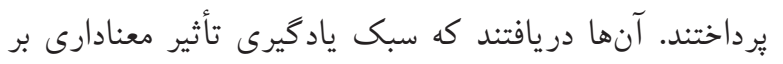
عملكرد تحصيلى و ميزان رضايتمندى دانشجويان از يادكيرى

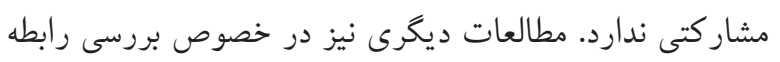

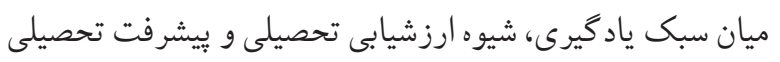




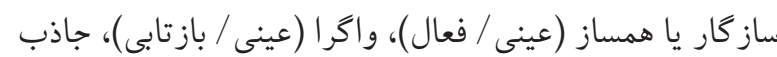
(انتز اعى / بازتابى) و همخرا (انتزاعى / فعال) (IV) (نمودار I).

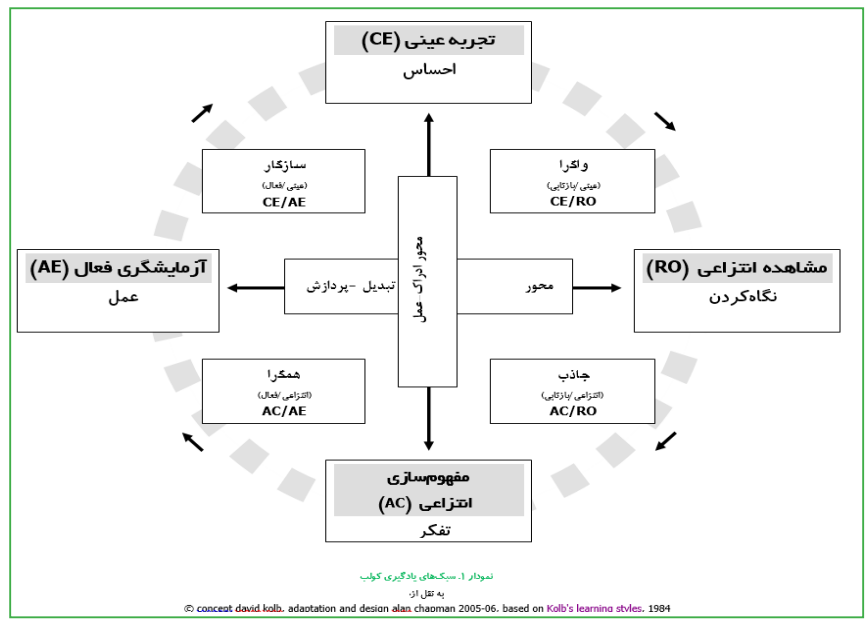

نمودار ا. سبك هاى يادگيرى كولب

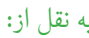

(C) concept david kolb, adaptation and design alan chapman 2005-06, based on Kolb's learning styles, 1984

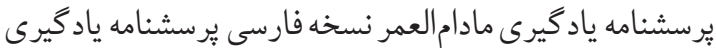

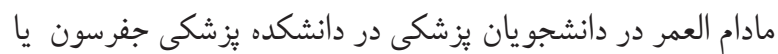

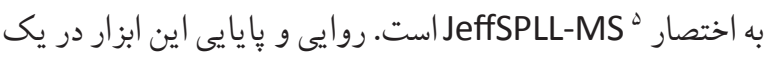

5. Jefferson Scale of Physician Lifelong Learning-Medical Students (JeffSPLL-MS)
اين هنكام توضيح مختصرى در رابطه با اهداف مطالعه به ايشان

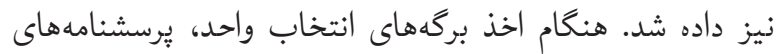
تكميلشده جمع آورى گرديد. اين مطالعه با تائيد كميته اخلاق

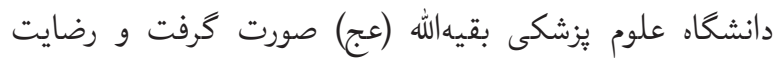
داوطلبانه دانشجويان براى شركت در مطالعه كرفته شد. بهمنظور گردآورى دادهها از يرسشناهه سه بخشى استفاده

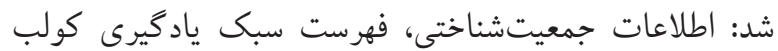

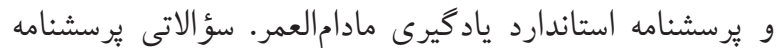
جمعيتشناختى شامل سن، جنس، وضعيت تأهل، محل سكونت،

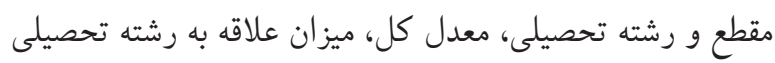
و ميزان مطالعه در طول روز بود. از نسخه فارسى برسشنامه كولب استفاده شد. روايى و پِايايى

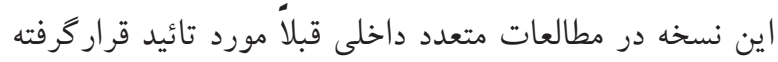

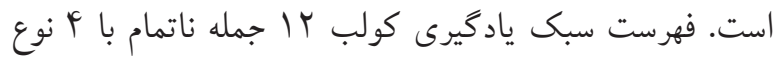

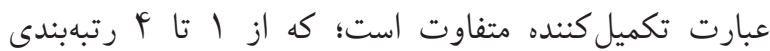
مىشوند. نمرات بهدستآمده بيانكر جهار نوع رويكرد يادكيرى (فعال، بازتابى يا تأملى، عينى و انتزاعى) است. اين رويكردها

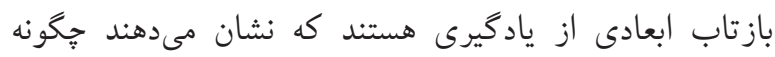

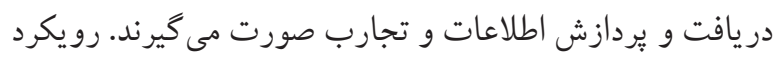
اول، كه تجربه عينى (CE) ' نام دارد، قطب مخالف رويكرد

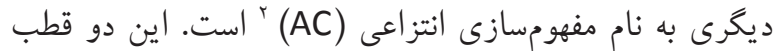

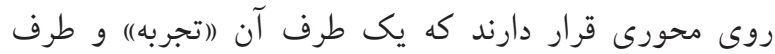
ديكر آن ((تفكر)) قرار دارد؛ يعنى محور ((تحويل)). دو قطب ديخر

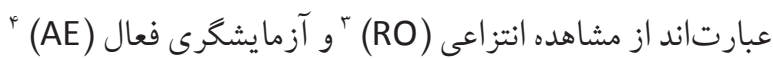
كه بر روى محورى قرار دارند كه يك طرف آن (عمل)) و طرف ديخر آن ((بازتاب)) قرار دارد؛ يعنى محور ((تبديل)).

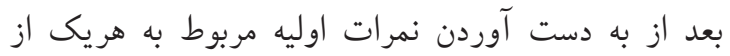
اين رويكردها، نمرات تركيبى براى هر محور محاسبه مىشود.

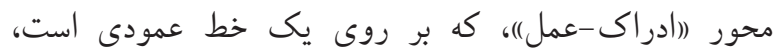

1. Concrete Experience (CE)

2. Abstract Conceptualization (AC)

3. Reflective Observation (RO)

4. Active Experimentation (AE) 
اعم از تغذيه، بهداشت حرفهاى و آموزش بهداشت به ترتيب در رتبههاى بعدى قرار داشتند. مطابق جدول ا مشخص تنها معدل تحصيلى داراى رابطه معنادار با سبك يادگيرى شناخته شد و ساير متغيرهاى جمعيتشناختى و تحصيلى رابطه معنادارى با داريا

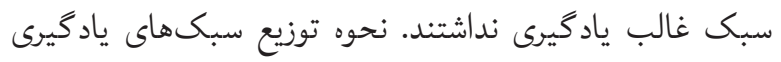
نيز در نمودار Y نشان دادهشده است. بر اين اساس، اكثريت

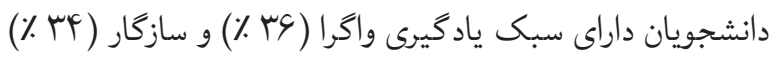

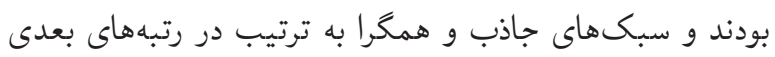
ازنظر ميزان فراوانى قرار داشتند.

جدول ا. سبك غالب ياد گيرى دانشجويان برحسب مشخصات جمعيتشناختى و تحصيلى ينى دادير

\begin{tabular}{|c|c|c|c|c|c|}
\hline \multirow{2}{*}{ 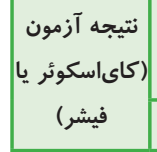 } & \multicolumn{4}{|c|}{ سبك غالب يادگيرى } & \multirow{2}{*}{ جمعيتشناختى } \\
\hline & جاذب & همكرا & سازگار & واكرا & \\
\hline \multirow{3}{*}{$\begin{array}{l}\mathrm{c}=|r / r| r \\
\mathrm{p}=\cdot / V \Delta .\end{array}$} & \multicolumn{5}{|c|}{ وضعيت سنى (سال) } \\
\hline & $r F(\mid N / q)$ & $\mid r(1 \cdot / r)$ & $r \&(r s / r)$ & $F F(r F / G)$ & كمتر از هr سال \\
\hline & $19(r \mu / r)$ & $\vee(\Lambda / \Delta)$ & $r \Delta(r \cdot / \Delta)$ & rl (rV/A) & $+r \Delta$ \\
\hline \multirow{3}{*}{$\begin{array}{l}\mathrm{F}=1 / \mathscr{\varphi} \varphi V \\
\mathrm{p}=\cdot / V^{\mu} \varphi\end{array}$} & \multicolumn{5}{|c|}{ جنسيت } \\
\hline & $\mu q(19 / 9)$ & $19(9 / \mathrm{V})$ & $99(\mathrm{rr} / \mathrm{V})$ & $V r(r s / v)$ & 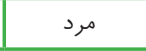 \\
\hline & $F(r \cdot / \Lambda)$ & $1(\mathrm{~V} / \mathrm{V})$ & $\Delta(r \Lambda / \Delta)$ & $r(r \mu / l)$ & زن \\
\hline \multirow{3}{*}{$\begin{array}{l}\mathrm{C}=r T / F F V \\
\mathrm{p}=\cdot / T r \Lambda\end{array}$} & \multicolumn{5}{|c|}{ وضعيت تأهل } \\
\hline & $r F(\mid N / r)$ & $10(11 / F)$ & $\operatorname{Rr}(r / / \Lambda)$ & $01($ rN/s) & 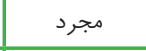 \\
\hline & $19(Y F / V)$ & $\Delta(\varphi / \Delta)$ & rq (rV/V) & $r F(r \mid / r)$ & متأهل \\
\hline \multirow{3}{*}{$\begin{array}{l}\mathrm{F}=r / \cdot \wedge \mathrm{F} \\
\mathrm{p}=\cdot / r \vee q\end{array}$} & \multicolumn{5}{|c|}{ محل سكونت } \\
\hline & $1 \wedge(Y Y / Y)$ & $\Delta(V / V)$ & $r \mid(r r / r)$ & $r \mid(r r / r)$ & بومى (تهران) \\
\hline & $r \Delta(\mid V / F)$ & $10(1 \cdot / 4)$ & $\Delta \cdot(r F / V)$ & $\Delta F(r V / \Delta)$ & غيربومى (ساير \\
\hline \multirow{4}{*}{$\begin{array}{l}\mathrm{F}=1 \cdot / 9 \cdot \vee \\
\mathrm{p}=\cdot / \cdot \vee 4\end{array}$} & \multicolumn{5}{|c|}{ ميزان علاقه به رشته تحصيلى } \\
\hline & $\cdot(\cdot / \cdot)$ & $r(1 \mu / \Gamma)$ & $V(F \& / V)$ & $G(F \cdot / \cdot)$ & هيج يا اندى \\
\hline & $\mid \mu(\mid \Lambda / \mu)$ & $11(10 / 0)$ & $r \mid(r q / s)$ & rs (rs/G) & 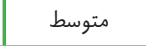 \\
\hline & $r \cdot(r F / F)$ & $\vee(\Delta / \mathrm{V})$ & $k r(r \Delta / \cdot)$ & $\operatorname{Fr}(r \Delta / \cdot)$ & 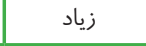 \\
\hline \multirow{4}{*}{$\begin{array}{l}c=r r / G \cdot G \\
p=\cdot / \wedge \Delta G\end{array}$} & \multicolumn{5}{|c|}{ ميزان مطالعه در روز (ساعت) } \\
\hline & $V(|V /|)$ & $\Delta(\mid r / r)$ & $10(r s / s)$ & $\mid F(r F / 1)$ & كمتر از 1 \\
\hline & $r \backslash(r \cdot / F)$ & $V(s / \Lambda)$ & rs $(r \Delta / \cdot)$ & rq (rV/q) & ا \\
\hline & $10(r \mu / 1)$ & $\wedge(\mid r / \Gamma)$ & $r \cdot(r \cdot / \Lambda)$ & $r r(r r / \Lambda)$ & $+r$ \\
\hline
\end{tabular}

مطالعه داخلى مورد تائيد قرارگرفته است (1)). اين ترسشنامه

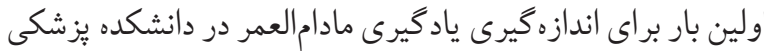

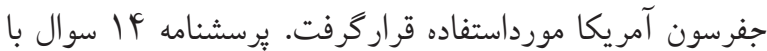

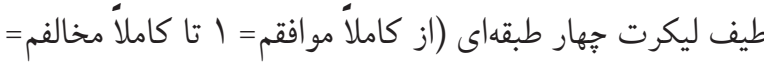

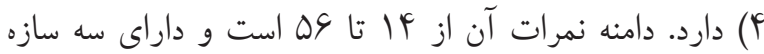

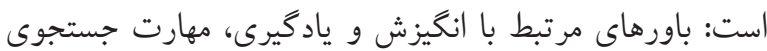
طلاعات و توجه به فرصتهاى يادكيرى. براى محاسبه نمره كل و

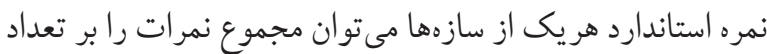

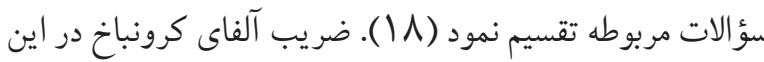
مطالعه قابلقبول بود ( (a=- م). براى تجز يهو تحليل دادهها از SPSS ب استفاده شد. براى آمار توصيفى، فراو انى و درصد هريك از متغيرهاى كيفى محاسبه گرديد و شاخصهاى مركزى اعم از ميانخين و انحر اف معيار متغيرهاى

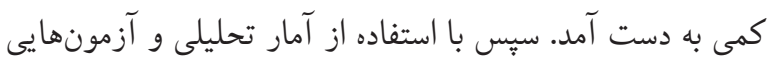
كاىاسكوئر يا فيشر روابط ميان متغيرهاى جمعيتشناختى و تحصيلى ارزيابى شد. روابط ميان سازهاى سبك ياد گيرى و ورئ

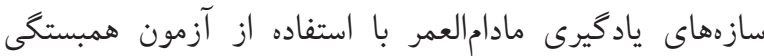

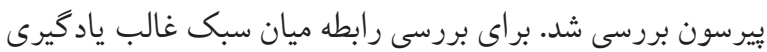

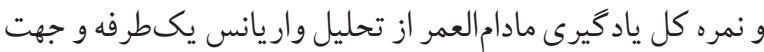
رسم ماتريس سبكهاى ياد گيرى از نمو دار ير اكنش ' استفاده شد.

يافته ها

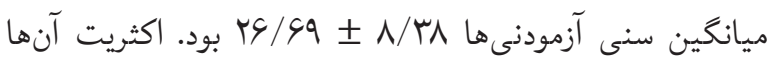

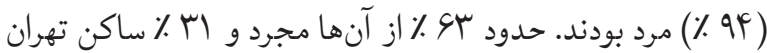
بودند. حدود 09 ٪ از شركت كنند مان علاقه زياد به رشته تحصيلى خود داشتند و تنها V ٪ علاقه خود را هيج يا اندك اعلام كردند.

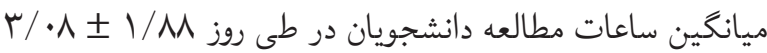

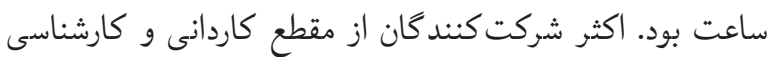

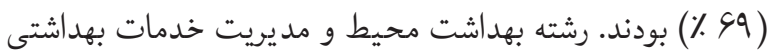

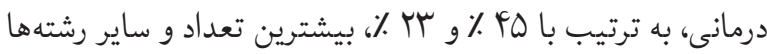


جدول r. ميانگين، انحراف معيار و دامنه تغييرات سازههاى سبك ياد ئيرى و يادخيرى مادام العمر

\begin{tabular}{|c|c|c|c|}
\hline دامنه تغييرات & انحراف معيار & ميانكين & مقياس / سازه \\
\hline \multicolumn{4}{|c|}{ سبك يادگيرى كولب } \\
\hline $\mid N / \cdots-F \Delta / \cdot \cdots$ & $\Delta / V \cdot r$ & $r r / I r F$ & مفهومسازى انتزاعى (AC) \\
\hline $\mid s / \ldots-F+/ .$. & $s / I r V$ & 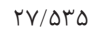 & تجربه عينى (CE) \\
\hline $\mid \Delta / \ldots-F F / \ldots$ & $\Delta / r \sim q$ & $r \cdot / r \Delta P$ & آزمايشكرى فعال (AE) \\
\hline$r \cdot / \cdot{ }^{\prime} r q / .$. & $F / \Lambda \Delta F$ & $r . / \cdot 19$ & مشاهده تأملى (RO) \\
\hline \multicolumn{4}{|c|}{ ياد ئيرى مادامالعمر } \\
\hline$r / \mid F-F / \cdots$ & $\cdot / 4 \cdot 1$ & $r / r \Delta r$ & باورهاى مر تبط با ياد گيرى و انكيزش \\
\hline $1 / \Delta \cdot-r / \cdots$ & $\cdot / \mathscr{A r}$ & $r / r \mid \Lambda$ & مهارت جستجوى اطلاعات \\
\hline $1 / \& V-F / \ldots$ & $\cdot / \mathbb{F r}$ & $r /|r|$ & توجه به فرصتهاى يادگيرى \\
\hline
\end{tabular}

رو ابط ميان ساز ههاى سبك ياد خيرى و ياد خيرى مادام العمر نشان

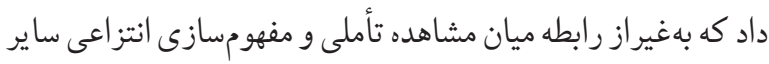
روابط ميان سازههاى سبك يادگيرى در سطح 1 •/•

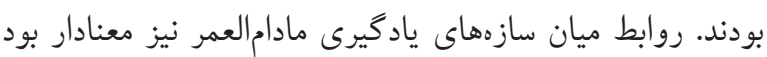

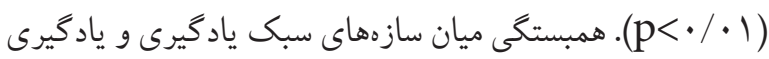

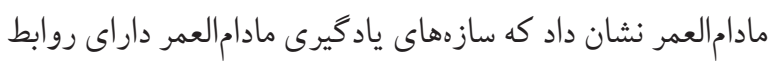

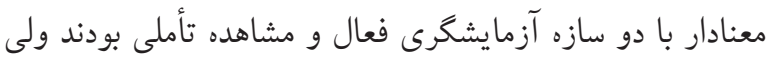

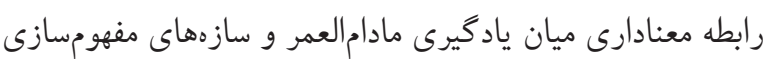
انتزاعى و تجربه عينى ملاحظه نشد (جدول ب).

\begin{tabular}{|c|c|c|c|c|c|}
\hline \multirow{3}{*}{$\begin{array}{l}\mathrm{C}=\cdot r / \varsigma q . \\
\mathrm{p}=\cdot / \wedge \vee \varsigma\end{array}$} & \multicolumn{5}{|c|}{ مقطع تحصيلى } \\
\hline & $r r(r r / l)$ & If $(9 / \mathrm{V})$ & FA $(r / 1)$ & $\Delta 1(\Gamma \Delta / r)$ & كارشارنى 9 \\
\hline & $11(1 V / T)$ & $G(9 / F)$ & $r \mu(r \Delta / q)$ & TF ( $r V / \Delta)$ & كارشناسى ارشد \\
\hline \multirow{4}{*}{$\begin{array}{c}\mathrm{C}=|\wedge r /| \cdot \uparrow \\
\mathrm{p}=\cdot / \cdot \varphi\end{array}$} & \multicolumn{5}{|c|}{ معدل تحصيلى } \\
\hline & $I V(r V / F)$ & $1 \cdot(\mid c / 1)$ & If $(r r / \varepsilon)$ & $r \mid(r r / q)$ & كمتر از 19 \\
\hline & YI (IV/A) & $f(r / F)$ & $F q(F / / \Delta)$ & $\mathcal{F F}(\Psi \gamma / \mu)$ & | 11 | 11 \\
\hline & $\Delta(\mid V / T)$ & $G(r \cdot / V)$ & $\wedge(Y Y / G)$ & 1. $(\mu F / \Delta)$ & r. \\
\hline
\end{tabular}

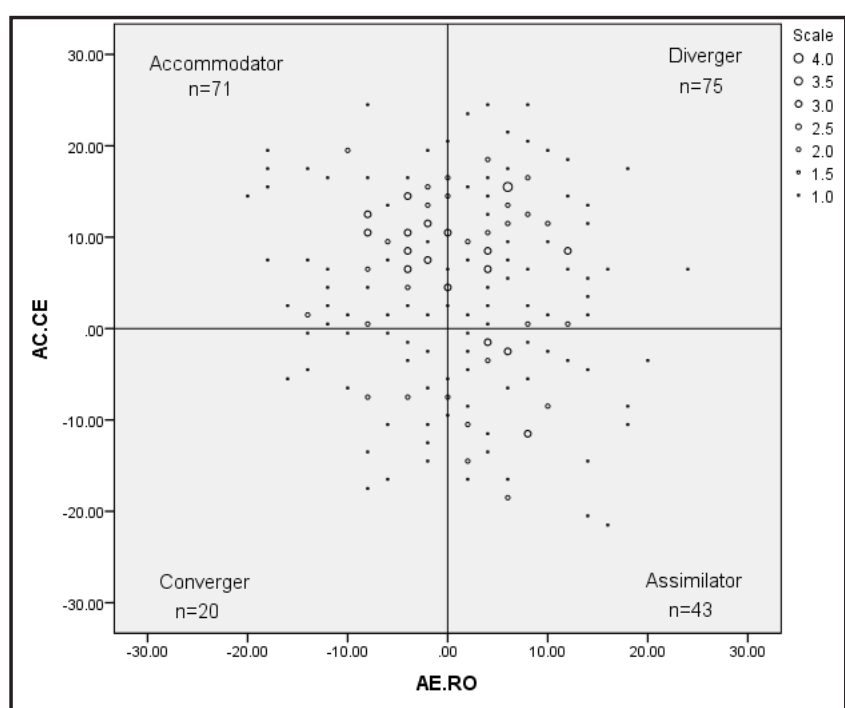

نمودار r. ماتريس سبك يادخيرى واحدهاى يثروهش بر اساس فهرست سبك يادگيرى كولب ينب

ميانگين و انحر اف معيار سازههاى سبك يادگيرى و يادگيرى

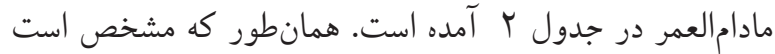
سازه مفهومسازى انتزاعى داراى بالاترين نمره و تجربه عينى

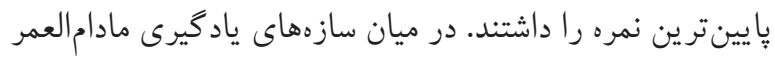

جدول س. روابط ميان سازههاى سبك يادگيرى و يادگيرى مادامالعمر

\begin{tabular}{|c|c|c|c|c|c|c|c|}
\hline (V) & (द) & $(\Delta)$ & (f) & 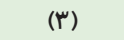 & (Y) & (1) & سازهها \\
\hline & & & & & & - & 1- مفهومسازى انتزاعى (AC) \\
\hline & & & & & - & -. $/ \Delta r \mid$ 米米 & r- تجربه عينى (CE) \\
\hline & & & & - & -./rsץ档米 & $-\cdot / r \Delta \mid$ 米米 & r- آزمايشكَى فعال (AE) \\
\hline & & & - &.$- / \mu F \Delta$ 米米 & -•/rSY 粎 &.$- / 1$ ro & عاه- مشاهده تأملى (RO) \\
\hline & & - & $-\cdot / r \mu \bigvee$ 米米 & ./桢米 &.$/ .1 f$ &.$/ r q$ & ه- باورهاى يادگيرى و انگيزش \\
\hline & - & . $/ 910$ 米米 & -・/r午人档米 & $\cdot /|V|$ 米 &.$/ .94$ & $-\cdot / \cdot r \mu$ & צ- مهارت جستجوى اطلاعات \\
\hline- & 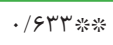 & ./OrV米米 &.$- / 199$ 米米 & •/几イ米 & $.1 .4 q$ &.- .1 .11 & V- توجه به فرصت هاى يادگيرى \\
\hline
\end{tabular}


سبك ياد گيرى كولب نشان داد كه رايجتر ين سبكهاى يادكيرى

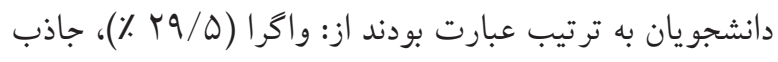

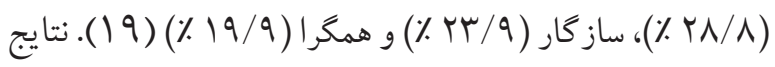
اين تحقيق همراستا با نتايج مطالعه حاضر بيانكر فراوانى بالاتر

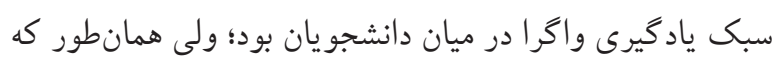

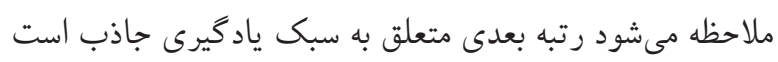

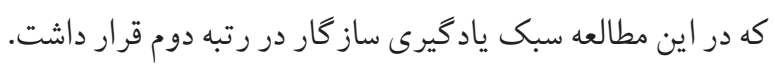

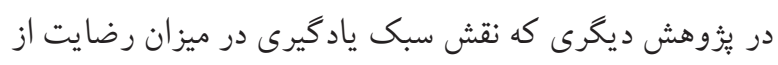

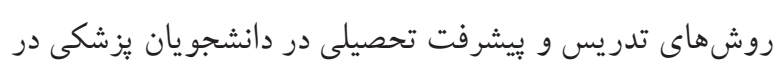

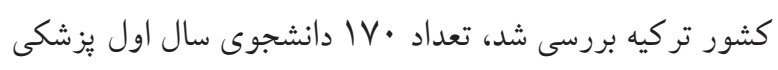

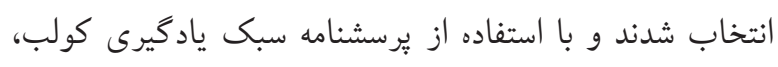
اطلاعات مربوط به سبك يادگيرى آنان جمع آورى شد (· (؟).

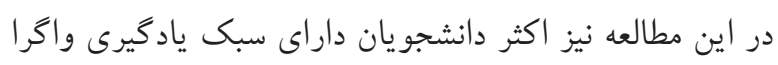

$$
\text { و جاذب (FV/V) }
$$

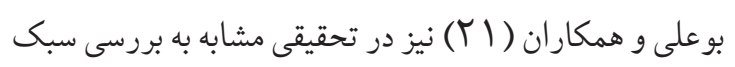
يادكيرى در ميان دانشجويان يزشكى كشور عربستان برداختند.

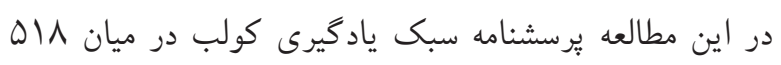

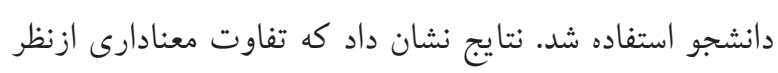

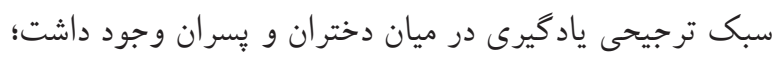

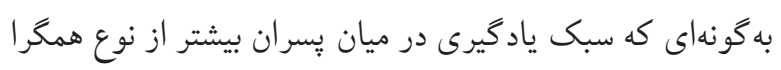

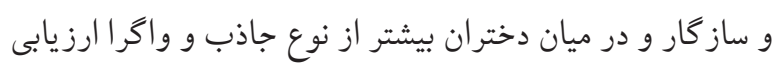

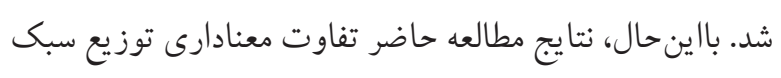
يادگيرى در ميان پيسران و دختران مشاهده نشد. شايد دليل

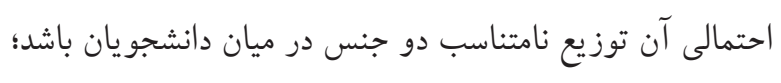

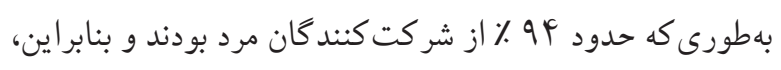
با اين وضع احتمال كشف اختلاف معنادار بين دو جنس به لحاظ آمارى بهشدت كاهش مى يابد.

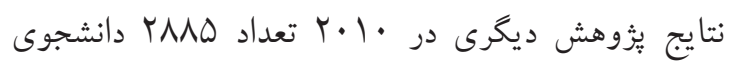

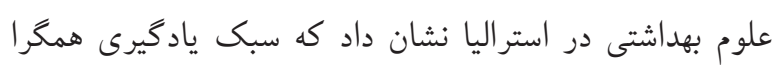

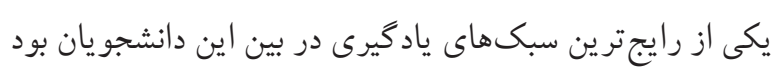

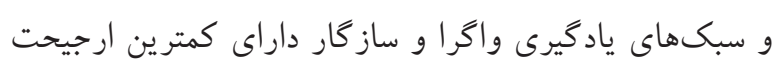

رابطه ميان سبكهاى جهار گانه ياد گيرى و نمره كل يادكيرى

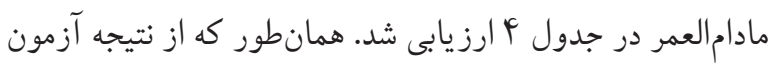

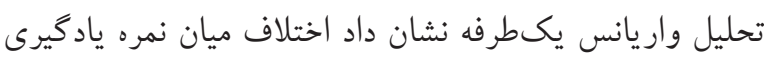

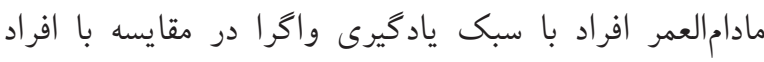

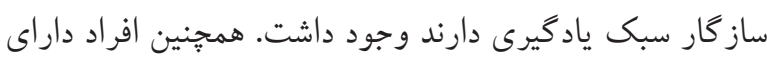

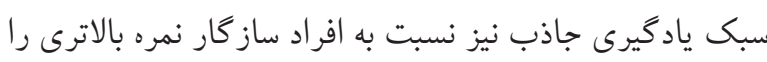
در يادگيرى مادامالعمر كسب نمودند. جدول عا. رابطه ميان سبكهاى يادگيرى جهار گَانه كولب و ميانغين

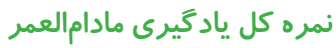

\begin{tabular}{|c|c|c|c|c|}
\hline $\begin{array}{l}\text { نتيجه آزمون } \\
\text { ANOVA }\end{array}$ & انحراف معيار & ميانكين & تعداد & سبك يادگيرى \\
\hline \multirow{2}{*}{$\begin{array}{l}\mathrm{F}=\Delta / \Delta \Lambda \\
\mathrm{P}=\cdot / \cdots 1\end{array}$} & זسץ/. & r/rFV & VD & واكرا \\
\hline & . & r/IFV & vi & سازكار \\
\hline \multirow{2}{*}{ جاذب>> واز } &.$/ 499$ & r/lis & $r$. & همكرا \\
\hline & $\cdot / \mu \cdot v$ & $r / \mu s V$ & pr & جاذب \\
\hline
\end{tabular}

ث مطالعه حاضر نشان داد كه سبكهاى يادگيرى واگرا و جاذب نسبت به ساير سبكها داراى فراوانى بيشترى بوده و از ميان

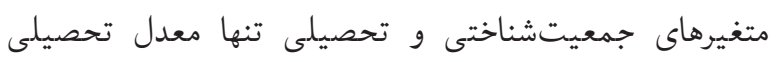

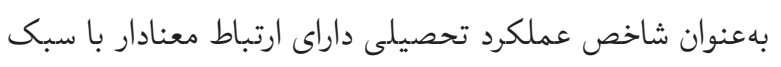

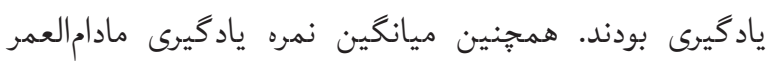
بيشتر داتشجويان وضعيت نسبتاً مناسبى داشت؛ كه البته امكان

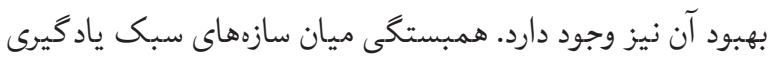
و ياد خيرى مادامالعمر نيز حاكى از وجود رابطه معنادار ميان اين

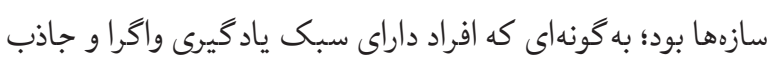
در مقايسه با آنهايى كه سبك ياد گيرى همخرا و سازگار داشتند داراى وضعيت بهترى ازلحاظ ياد كيرى مادامالعمر برآورد شدند. مطالعات فراوانى جهت شناخت سبكهاى يادكيرى در ميان دانشجو يان رشتههاى مختلف بز شكى و بهداشتى صورت كرفته

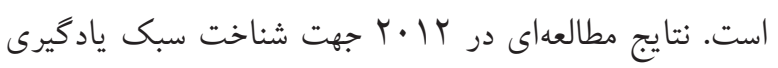

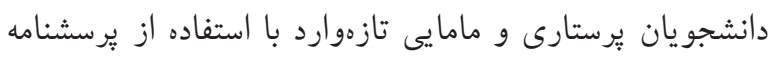


ميان سبك ياد گيرى مقاطع مختلف ملاحظه نغرديد. البته توزيع

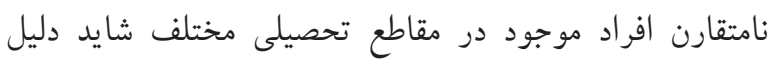

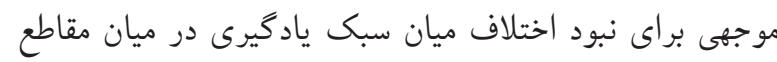
مختلف باشد.

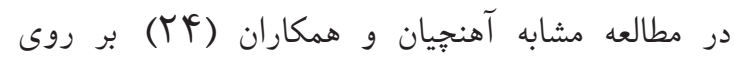
دانشجويان برستارى و مامايى دانشكاه مشهد نيز سبك ياد كيرى واخرا بهعنوان رايجترين سبك غالب يادگيرى در ميان ايشان ئن

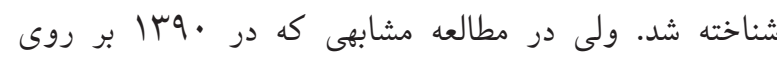

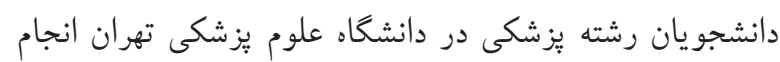

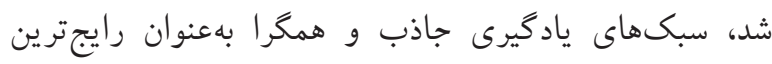

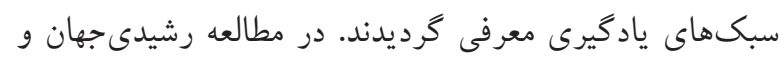

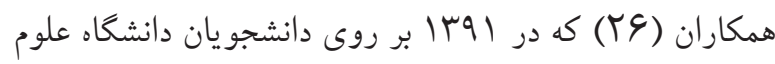
يزشكى بقيهالله (عج) صورت گرفت، سبكهاى ياد گيرى واخرا

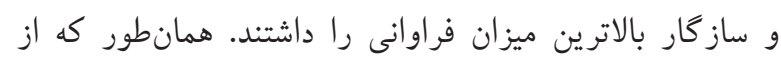

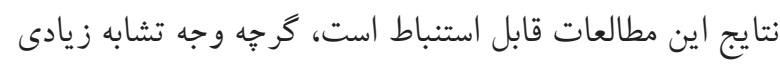
بين مطالعات مختلف ازلحاظ توزيع سبكهاى يادگيرى وجود

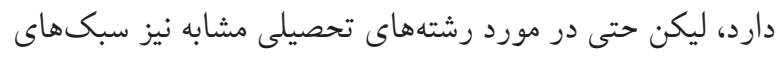

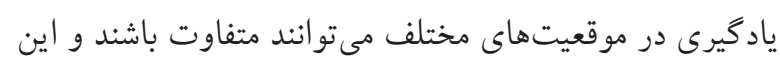

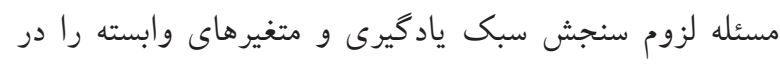

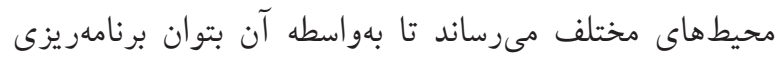
آموزشى مناسبى را براى موقعيتهاى متفاوت ترتيب دادي ماد.

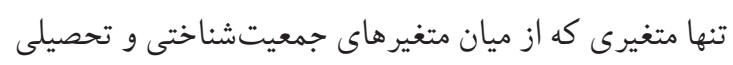

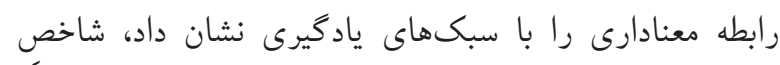
عملكرد تحصيلى يا همان معدل تحصيلى افراد در زمان انجام مطالعه بود. توزيع فراوانى سبكهاى جهار گانه يادگيرى در ميان

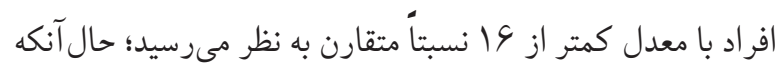

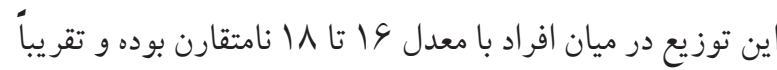
اكثر افراد واجد سبكهاى يادگيرى واكرا و ساز كار بودند. البته

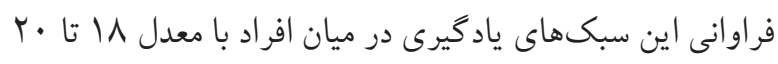

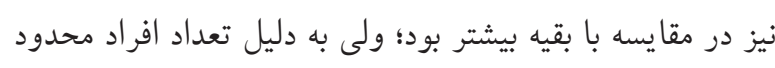

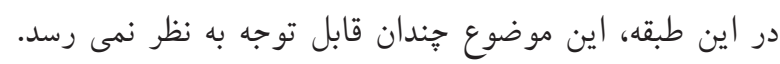

را داشتند (Tr). علىرغم اينكه اين مطالعه قرابت زيادى به لحاظ رشته با اين مطالعه داشت ولى نتايج آن كاملاً در تضاد با يافتهاى اين يُووهش بود. بنابراين، شايد بتوان با مقايسه اين

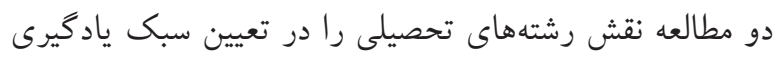
ناجيز دانست. زيرا در مطالعه حاضر نيز رابطه معنادارى نيز ميان نوع رشته تحصيلى و سبك يادگيرى غالب نيز به دست نيامد.

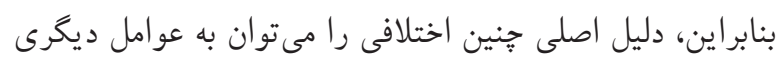

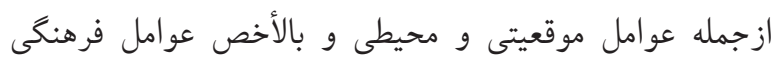
نسبت داد. در ايران نيز مطالعات زيادى بر روى سبك يادگيرى

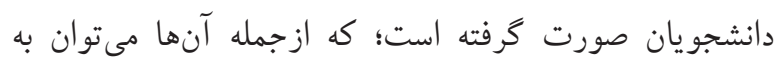
مطالعه عباسزاده و همكاران (YT) و آهنجيان و همكاران اشاره نمود. نتايج مطالعه عباسزاده و همكاران بين (YT) دانشجويان يُرستارى و مامايى شهر كرمان نشان داد كه توزيع

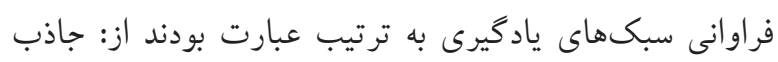

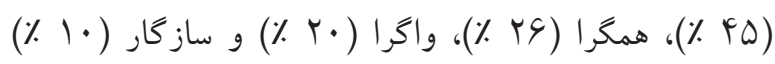

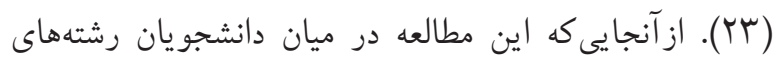
يرستارى و مامايى كه عمدتاً زن هستند انجامشده بود، شايد دليل

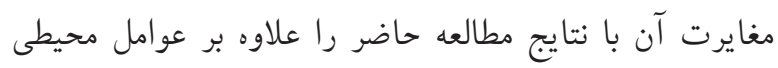

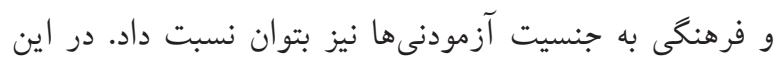

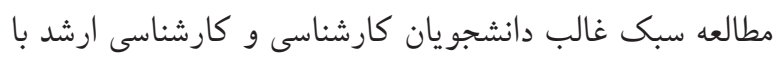

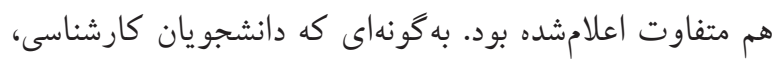
سبك يادكيرى جاذب را ترجيح مىدادند، ولى سبك يادگيرى مورد ترجيح دانشجو يان مقطع ارشد از نوع همكرا ا ارزيابى كرديد.

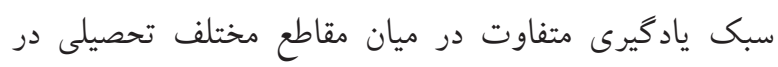

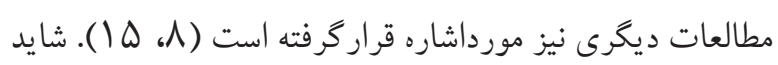
توجيه آن را بتوان در اظهارات كولب در رابطه با تغييرات بطئى نوردئ و تثبيت سبك ياد كيرى با كذشت زمان يافت. وى خاطرنشان

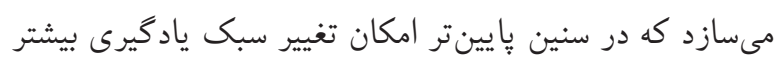

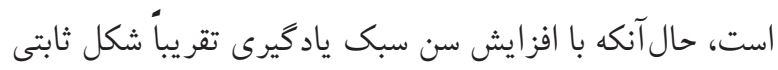

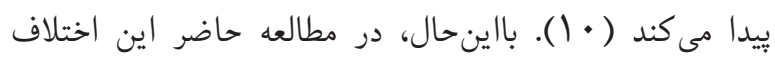


برخى از سازههاى سبك يادگيرى و مفهوم يادكيرى مادام العمر

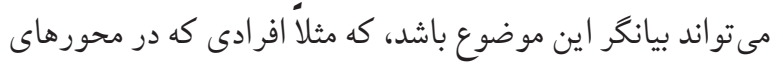

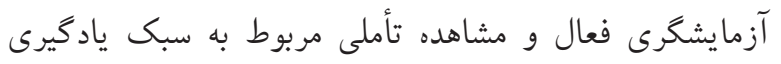

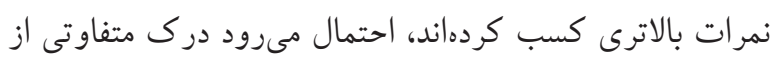
مفهوم ياد كيرى مادامالعمر داشته باشند. بنابراين اين افراد شايد تلاش بيشترى براى رسيدن به يادگيرى مادام العمر نمايند. از

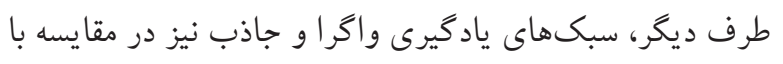

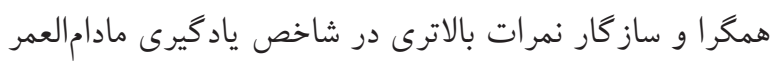

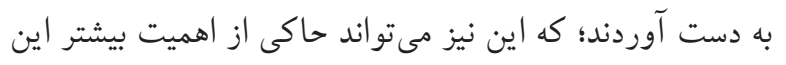

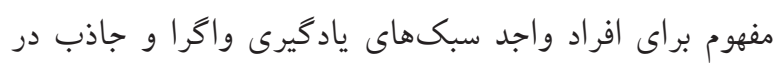
مقايسه با ساير ين باشد. علىرغم روابط معنادارى كه در زمينه ارتباط عملكرد

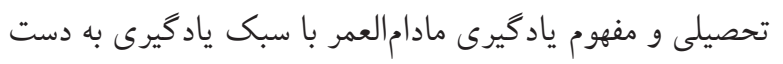

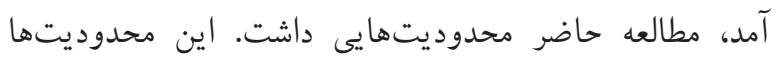

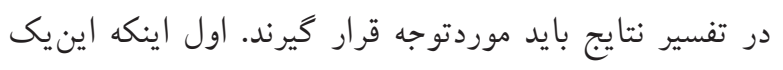

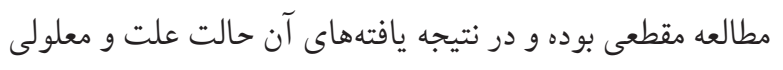

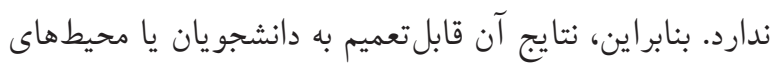

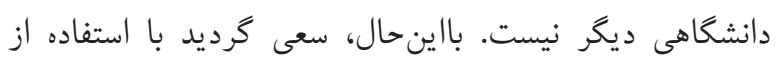

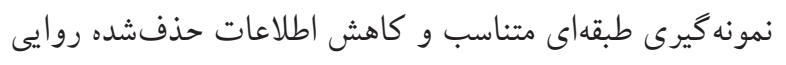
درونى مطالعه حتى المقدور تقويت گردد. ازآنجايىكه دادههاى

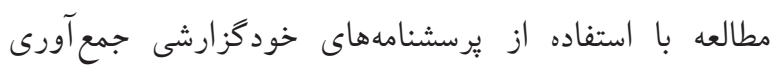

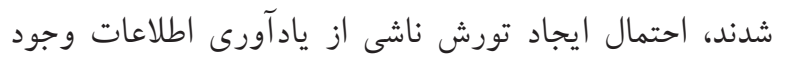

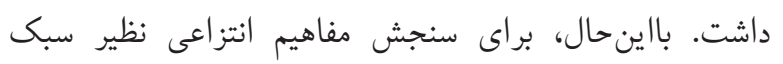
يادكيرى و يادكيرى مادامالعمر تاكنون ابزار عينى مناسبى ابداع نكرديده است. لذا اين مفاهيم لاجرم مى بايست با استفاده از

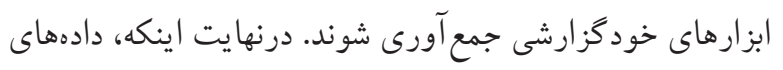

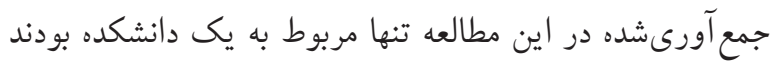

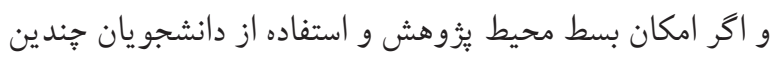

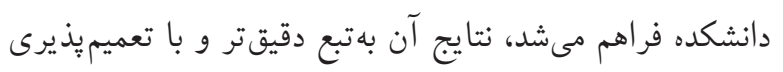

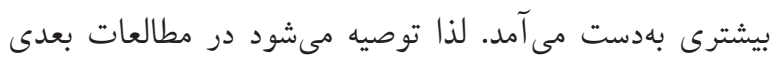

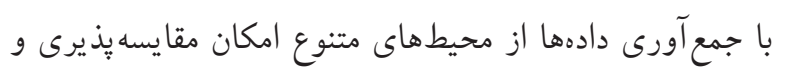

بالينحال، نمىتوان كفت كه دو سبك يادگيرى در مقايسه با

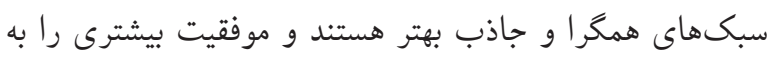
همراه دارند؛ زيرا سبك ياد گيرى يك مفهوم رتبهاى نيست بلى بلكه

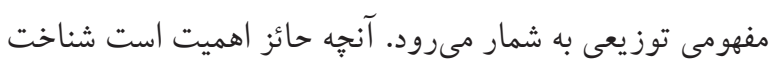

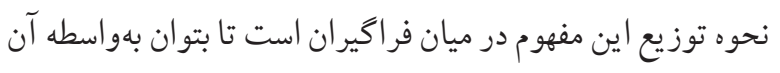

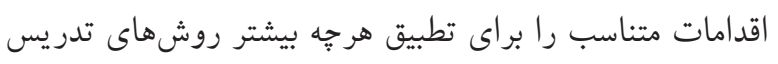

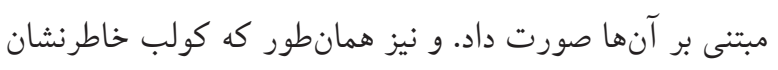

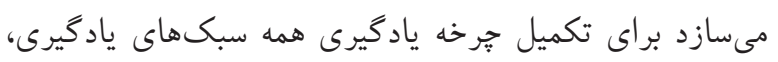

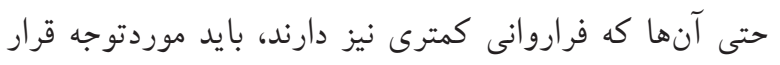
كيرد تا ياد خيرى كامل رخ دهد (IV)

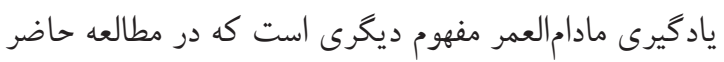

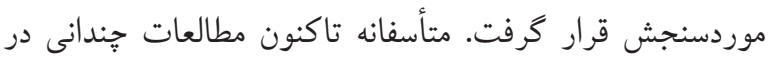

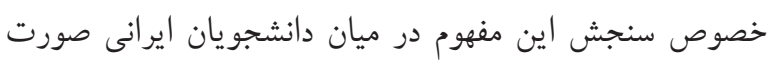
نكخرفته است. بر اساس تعريف انجمن يادكيرى مادامالعمر ارويا،

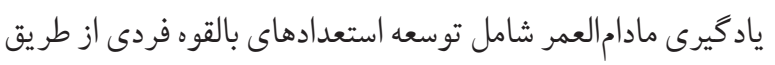

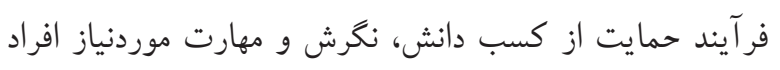

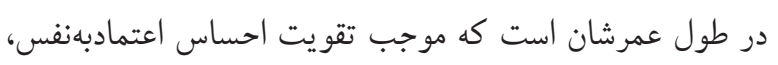

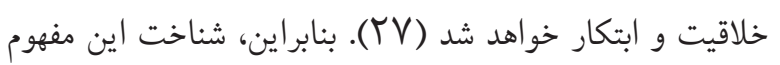

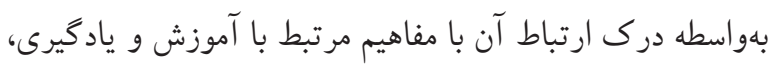

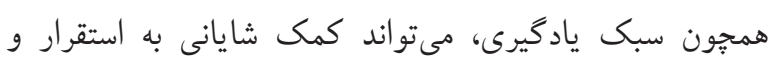

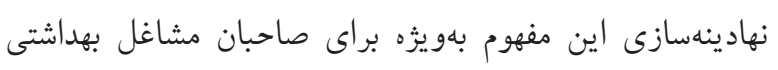

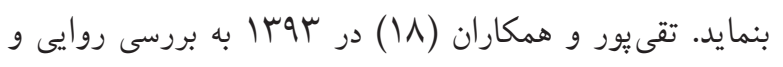

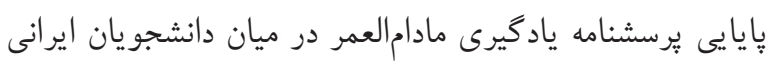

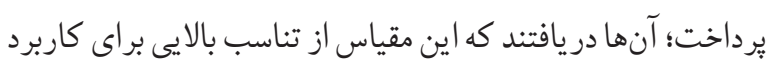

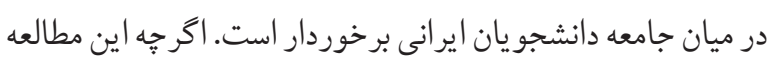

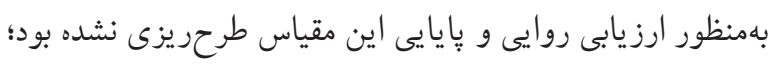

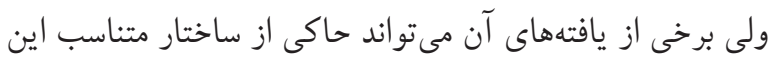

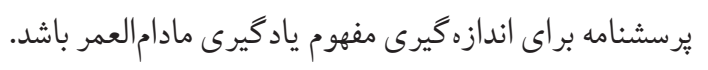

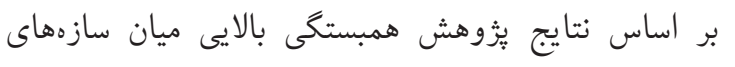

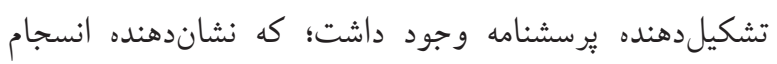
درونى يُرسنامه است. از سوى ديكر، روابط معنادار ميان 

بالاترى نسبت به ساير سبكهاى يادگيرى بودند. بنابراين، لزوم بر سبك يادگيرى افراد و جهت تقويت يادگيرى مادام العمر در توجه بيشتر به آنها براى شروع جرخه ياد گيرى و تنظيم روشهاى دانشجويان حوزه سلامت ترتيب داد تا لزوم كسب مهارتهاى حرفهاى متناسب با شيوه ترجيحى دانشجويان براى يادگيرى، بيشازييش موردتوجه قرار كيرد.

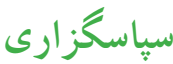

بدينوسيله از معاونت آموزش دانشكده بهداشت دانشگاه علوم يزشكى بقيهالله (عج) كه امكان انجام اين بُزوهش را فراهم ساختند تشكر مى كردد. در ضمن مطالعه حاضر نتيجه طرح تحقيقاتى مصوب دانشخاه علوم پيزشكى بقيهالهه (عج) است. تدريس منطبق بر آنها مىتواند موردتوجه قرار كيرد. ممكن است افرادى كه داراى سبك يادگيرى واگرا و جاذب هستند در مقايسه با آنهايى كه سبك ياد گيرى همگرا يا سازگار دارند اهميت بيشترى براى مفهوم يادگيرى مادامالعمر قائل گردند؛ كه اين موضوع نيازمند بررسىهاى بيشتر مى باشد. نقش متغيرهاى تحصيلى نظير معدل تحصيلى افراد در تبيين سبك يادگيرى آنها حائز اهميت بوده و ممكن است روابط علت و معلولى ميان اين متغيرها برقرار باشد؛ كه سنجش آن با استفاده از مطالعات مداخلهاى و طولى توصيه مى گردد. درنهايت، نظر به وجود برخى

\section{References:}

1. Thompson C, Crutchlow E. Learning style research: a critical review of the literature and implications for nursing education. Journal of professional nursing: official journal of the American Association of Colleges of Nursing. 1993 Jan-Feb;9(1):34-40. PubMed PMID: 8421126.

2. Romanelli F, Bird E, Ryan M. Learning styles: a review of theory, application, and best practices. American journal of pharmaceutical education. 2009 Feb 19;73(1):9. PubMed PMID: 19513146. Pubmed Central PMCID: 2690881.

3. Biggs JB. Teaching for quality learning at university: what the student does. 2nd ed. Buckingham; Philadelphia, PA: Society for Research into Higher Education: Open University Press; 2003. xii, 309 p. p.

4. Andreou C, Papastavrou E, Merkouris A. Learning styles and critical thinking relationship in baccalaureate nursing education: a systematic review. Nurse education today. 2014 Mar;34(3):362-71. PubMed PMID: 23830067.

5. Klitmoller J. Review of the methods and findings in the Dunn and Dunn learning styles model research on perceptual preferences. Nord Psychol. 2015 Jan 2;67(1):2-26. PubMed PMID: WOS:000349466900002.

6. Fleming $\mathrm{CT}$, Garner JB. Brief guide for teaching adult learners. Marion, Ind.: Triangle Publishing; 2009. 92 p. p.

7. Partridge L. Managing change: learning made simple. 1st ed. Oxford England; Burlington, MA: ButterworthHeinemann; 2007. v, 122 p. p.

8. Vaughn LM, Battle JM, Taylor T, Dearman L. Learning styles

and the relationship to attachment styles and psychological symptoms in college women. College Student Journal. 2009;43(3):723-35.

9. Wehrwein EA, Lujan HL, DiCarlo SE. Gender differences in learning style preferences among undergraduate physiology students. Advances in physiology education. 2007 Jun;31(2):153-7. PubMed PMID: 17562903.

10. Kolb AY, Kolb DA. Learning styles and learning spaces: Enhancing experiential learning in higher education. Acad Manag Learn Edu. 2005 Jun;4(2):193-212. PubMed PMID: WOS:000233108100008. English.

11. Hojat M, Veloski JJ, Gonnella JS. Measurement and Correlates of Physicians' Lifelong Learning. Acad Med. 2009 Aug;84(8):1066-74. PubMed PMID: WOS:000270711400017. English.

12. Haery, S. M., Tehrani, H., Olyaeimanesh, A., \& Nedjat, S. (2016). Factors Influencing the Social Health of Employees of the Ministry of Health and Medical Education in Iran. Iranian Journal of Health Education and Health Promotion, 3(4), 311-318.

13. Wang X.C, Hinn M, Kanfer AG. Potential of computersupported collaborative learning for learners with different learning styles. Journal of Research in Technology in Education. 2001;34(1):74-85.

14. Li YS, Chen HM, Yang BH, Liu CF. An exploratory study of the relationship between age and learning styles among students in different nursing programs in Taiwan. Nurse education today. 2011 Jan;31(1):18-23. PubMed PMID: 
WOS:000286857700005.

15. Li YS, Chen PS, Tsai SJ. A comparison of the learning styles among different nursing programs in Taiwan: Implications for nursing education. Nurse education today. 2008 Jan;28(1):70-6. PubMed PMID: WOS:000252903800010.

16. Liew SC, Sidhu J, Barua A. The relationship between learning preferences (styles and approaches) and learning outcomes among pre-clinical undergraduate medical students. Bmc Med Educ. 2015 Mar 11;15. PubMed PMID: WOS:000353632400001.

17. Kolb D.A. The Cycle of Learning (Version 3.1). Boston: Hay Group Holdings, Inc; 2005.

18. Taghipour A KF, Mousavi Bazaz SM, Khosravi Z, Abdolahi $M$, Factor Structure and Reliability ofthe Persian Version of the Jefferson Scale of Physician Lifelong LearningMedical Students(JeffSPLL-MS). Iranian Journal of Medical Education. 2015;14(11):990-9. [Persian]

19. D’Amore A, James S, Mitchell EKL. Learning styles of firstyear undergraduate nursing and midwifery students: $A$ cross-sectional survey utilising the Kolb Learning Style Inventory. Nurse education today. 2012 Jul;32(5):506-15. PubMed PMID: WOS:000306447800008.

20. Gurpinar E, Alimoglu MK, Mamakli S, Aktekin M. Can learning style predict student satisfaction with different instruction methods and academic achievement in medical education? Advances in physiology education. 2010 Dec;34(4):192-6. PubMed PMID: WOS:000284533400006.

21. Buali $\mathrm{WH}$, Balaha $\mathrm{MH}$, Muhaidab NS. Assessment of learning style in a sample of saudi medical students. Acta informatica medica: AIM: journal of the Society for
Medical Informatics of Bosnia \& Herzegovina: casopis Drustva za medicinsku informatiku BiH. 2013;21(2):838. PubMed PMID: 24058248. Pubmed Central PMCID: 3766540.

22. Zoghi M, Brown T, Williams B, Roller L, Jaberzadeh $S$, Palermo $\mathrm{C}$, et al. Learning style preferences of Australian health science students. Journal of allied health. 2010 Summer;39(2):95-103. PubMed PMID: 20539932.

23. Abbaszadeh A JN, Najafi Kalyani M,. Comparison of learning styles of Nursing Students in Razi Nursing School, Kerman University of Medical Sciences Studies in Development of Medical Education. 2012;8(2):195-9. [Persian]

24. Ahanchian $M$, Mohamadzadeghasr A, Garavand $H$, Hosseini A. Prevalent Learning Styles among Nursing and Midwifery Students and its Association with Functionality of Thinking styles and Academic Achievement; a Study in Mashhad School of Nursing and Midwifery. Iranian Journal of Medical Education. 2012;12(8):577-88. [Persian]

25. Ghajarzadeh M, Adili-aghdam F. Learning styles of medical residents of different disciplines in Tehran University of Medical Sciences. Razi Journal of Medical Sciences. 2012;19(94):27-32. [Persian]

26.Rashidi-jahan H, Saffari M, Sanaeinasab H, Pakpour A, Khajehazad M. Learning styles of students of Baqiyatallah University of Medical Sciences in 2012. The Journal of Medical Education and Development. 2013;8(1):52-64. [Persian]

27. Caltone MP. Handbook of lifelong learning developments. New York: Nova Science Publishers, Inc.; 2010. xviii, 408 p. p. 